\title{
Effect of Google Classroom on Academic Achievement of Undergraduate Students in Computer Database Management System in Universities in South East Nigeria
}

\author{
Omeh basil, $^{1}$, Chioma umakalu ${ }^{2}$, Emma Nwangwu ${ }^{3}$ \\ ${ }^{1}$ Assistant Professor of Department of computer and robotics education university of Nigeria \\ christian.omeh@unn.edu.ng \\ ${ }^{2}$ Assistant Professor Department of Computer Science, Enugu state university of science and technology, Nigeria \\ chioma.umakalu@unn.edu.ng \\ ${ }^{3}$ Associate Professor Department of computer and robotics education university of Nigeria \\ emmanuel.nwangwu@unn.edu.ng
}

\begin{abstract}
The study was carried out to determine the effect of Google classroom on the academic achievement of undergraduate students in computer database management systems in universities in Enugu state. A quasi-experimental research design was adopted for the study and intact classes were assigned to the treatment group. The population for the study comprised all 136 third-year computer education students in universities in south east Nigeria that offers database management system. Two research questions were posed and two hypotheses were formulated to guide the study. Mean and standard deviation was used to analyze the research question Analysis of covariance (ANCOVA) was used to test the hypotheses of no significant difference at 0.05 level of significance. It was found out that there is no interaction effect, academic achievement of treatment group improved better than control group in the database management system. Based on the findings, it was recommended that lecturers teaching database management systems should integrate into teaching practices, the use of Google classroom in instructional method.
\end{abstract}

Keywords: Google Classroom, Academic Achievement, Retention, Database management

\section{Introduction}

The world of work has revolutionized as a result of technology, climate change, covid-19 and globalization. Therefore, these challenges both the teacher and student in the acquisition of innovative methods and new skills for teaching and learning (Kalyani \& Rajasekaran, 2018; Majherová \& Králík, 2017; Nicolaides, 2012). According to Numonjonov, (2020), the application of innovative methods in teaching through the use of technology is a new normal which have come to stay. Khamroevich, (2021), argues that many technological tools that aid teaching such as computer-aided instruction (CAI) (Li, Zhang \& Zhao, 2021), authoring tools (Pachacama, Cuascota, \& Guerrero, 2021), cloud computing, google classroom (Gupta \& Pathania, 2021), google data studio, among others, should be incorporated into teaching and learning process. Perhaps, students' unpreparedness to embrace the google classroom which is the new normal has affected the educational process especially during Covid-19 (Oktaria, \& Rahmayadevi, 2021). Google classroom integrates newer techniques and technology into the classroom for effective and efficient teaching and learning (Francom, Schwan \& Nuatomue, 2021). Google classroom as explained by Ismail, Mustakim, and Samad, (2021) that it aids students in developing critical thinking, information literacy, collaboration, problem-solving skills and communication skills.

However, Gleason and Heath, (2021) oppose the idea that google classroom can only serve as a tool for instructional delivery. Also, the author explains that attention should not be on Google classroom alone but the use of Google classroom for effective teaching and learning process. While Al-Maroof and Salloum (2021), contend that Google classroom should be separate from instructional development and delivery. Google classroom is one of the G-suit software, is an online learning management system. Some researchers have been conducted using Google classroom as an innovative pedagogical tool (Huang, Liu, Chen, \& Tsai, 2021; Thomas, 2021). According Abid Azhar and Iqbal (2018), said that google classroom can be 
effectively integrated into teaching and learning through the use of innovative pedagogy.

Researches have shown that innovative pedagogies are in the front line of discussion in academic discussions (Olimov, 2021; Süer \& Oral, 2021), while is yet to establish its effectiveness in developing country like Nigeria (Emelife, 2021). Researches have argued that the use of modern technology in Nigeria is poor as a result of being non-compliant with innovative pedagogical tools (Obaroakpor, Dikenwosi \& Obaroakpor, 2021; Aguboshim, Onwuka, Obiokafor, \& Oboti, 2021). Innovative pedagogical tools are the instructional technological tool that aid students to participate actively in either virtual or real classrooms (Korucu-Kış, 2021). They are instructional methods applied by teachers as a modification or value-added to the traditional method. It aids in teaching task-oriented courses like computer programming, database management, mathematics among others (Fakhimuddin, Khasanah, \& Trimiyati, 2021; Luik, \& Lepp, 2021).

In addition, studies have shown that lecturers still use the traditional method in teaching and learning database management systems (Yelamali \& Beelagi, 2021). The adoption of an innovative pedagogical tool like google classroom is still is low (Olelewe. 2020). This affects the students' academic achievement, interest and retention most time including in database management (Oguguo, Nannim, Agah, Ugwuanyi, Ene \& Nzeadibe, 2021; Ataei, 2021). Moreover, students interest always affect learning. It also aids students to acquire the skills necessary for employment or become self-reliant (Onyepunuka, Fumnanya \& Eze, 2021; Ovchinin, Kuligina \& Tarlakovskaya, 2021), database management system was selected for this study because of computer education students' poor academic achievement and interest in the course (Ivongbe, Abdulsalami \& Omorogbe, 2021; Naik \& Gajjar, 2021). Ouatik and Ouatik, (2021) advocate for the use of an innovative pedagogical tool to reduce students' poor academic achievement in the database management system. Due to the strength of innovative pedagogical methods such as technology-based learning, context-based learning, formative analytics learning with modern tools like drones, google classroom and problem-based learning (Carlos, 2021; Getz, Mathew \& Shin, 2021). From the above, this study adopts context-based learning (CBL) and problem-based learning (PBL) using the google classroom platform to seek their effect in teaching and learning of database management system courses.

CBL approach involves the use of context as a means of establishing concepts, it aids the student to take the responsibility for their learning, it requires emphases appropriate to context and demands adaptation of science (De Putter-Smits et al., 2013). This teaching strategy puts the learner, the content and their interaction around the context of learning (Jeon-Ellis, Debski \& Wigglesworth, 2005), Its main purpose is to support the students in understanding and making learning meaningful to students by connecting the subject matter contents to their personal, social, and cultural life situations (Baker et al., 2009; De Jong, 2008; Yu et al., 2015). Furthermore, CBL mainly focuses on the use of contexts and application of science as a means of enhancing the scientific understanding of students' real-worlds while developing students' capacities to function as responsible participants in their everyday lives (Aikenhead, 2006; Bennett et al., 2007).

Furthermore, different authors have defined PBL. According to Khan and Sobani (2012), PBL is an instructional method of hands-on active learning, centred on the investigation and resolution of simulated real-world problems. According to Savery (2015) defined PBL as an instructional learner-centred approach, which empowers learners to conduct research, integrate theory and practice, and apply knowledge and skills to develop a viable solution to a defined problem. PBL is an approach to instruction that prepares learners for real-world experience and causes them to learn how to research (Sgroi \& Ryniker, 2002). The facilitator of PBL usually directs and guides the students without essentially resorting to a lecture-based teaching method. This turns learning into a group exercise and thus involves teamwork. According to Balan, Yuen and Mehrtash, (2019), PBL challenges students with an open-ended, ill-structured, real-world problem and they are made to work in groups to classify learning needs and develop possible solutions, with teachers who serve as guides rather than lecturers. Today, PBL is used in a variety of courses and disciplines, such as medicine, sciences, and education. Studies like Albanese and Mitchell (1993) compared the efficacy of PBL and lecture-based method (LBM) in the medical literature; science subjects, (Khairani, Suyanti \& Saragi, 2020) health sciences, (Northwood, Northwood, \& Northwood, 2003). At the time of this study, no study has been carried out to determine the efficiency of CBL and PBL using Google classroom in improving students' academic achievement of students in database management, which is the objective of this study. The study supports constructivist learning theory.

Constructivist learning theory holds that learners actively construct knowledge through inference from prior experience (Chan \& Elliott, 2004). The learner builds upon previous experience to develop new knowledge from new exposures. We determine how combing CBL and PBL would influence the students' learning outcomes by selecting two database management classes (one taught using CBL \& PBL combine and the other using LBM).

\section{Purpose of the Study:}

1. The mean achievement scores of undergraduate students taught database management combining $\mathrm{CBL}$ and PBL strategy using google classroom and those taught with lecture method

2. The interaction effect of treatment and gender on achievement scores of students taught database management

\section{Hypotheses}

-Ho1: There is no significant difference in the mean achievement scores of undergraduate students taught database management combining CBL and PBL strategy using google classroom and those taught with lecture method.

- Ho2: There is no significant difference in the mean achievement scores of male and female undergraduate students taught database 
management combining CBL and PBL strategy using google classroom.

\section{Methodology:}

An experimental research design was adopted for this study. The study was carried out in the Nnamdi Azikwe University Awka and Enugu State University of Science and Technology in Enugu state Nigeria. The population for the study was 136 computer education students comprised of 58 students from Nnamdi Azikwe University Awka and 78 students from Enugu state university of science and technology. The instrument used for data collection was the database management achievement test (DBMAT). DBMAT has 35 multiple choice questions having four alternatives. DBMAT was administered as a pre-test and reshuffled for post-test. The multiple-choice question was developed using blooms taxonomy of cognitive domain. the lesson plan was developed by the researcher as an instructional guide for instructional delivery of the content. DBMAT and lesson plan was validated by three research experts from the department of computer education and measurement and evaluation at the University of Nigeria. As to ensure content validity of the test and lesson plan. Kuder-Richardson formula (KR-20) was used to determine the internal consistency and relative stability of DBMAT. NAU was used as the treatment group while ESUT was the control group. The treatment group was taught using combining CBL and PBL using google classroom while the control group was taught using LM. The course was taught using the lecturers and technologists in the department. The data collected was analyzed using, mean, the standard deviation for the research question and analysis of covariance (ANCOVA) for the hypothesis. The hypothesis formulated was tested at a 0.05 level of significance.

\section{Design:}

The design of this study was non-randomised control groups. A quasi-experimental design is one in which intact classes or preexisting groups serve as the experimental and control groups rather than random sampling and group assignment. The intact group was utilized in this study to avoid interfering with normal school schedules and activities at the universities that participate in the study. However, the intact classes were randomly assigned to the experimental and control groups through a toss of a coin. Any intact class that scores a head was assigned to the experimental group (Google classroom) and any class that scores a tail was assigned to a control group (LM) as shown in Table 1

Table (1): the randomized pretest and posttest control group design

\begin{tabular}{lccccc}
\hline Group & Non-R & Pretest & Treatment & Postest & Retention \\
\hline Experimentil (E) & NR & 01 & $X$ & 02 & 03 \\
& & & 1 & & \\
Coutrol (C) & NR & 01 & - & 02 & 03 \\
\hline
\end{tabular}

NR: Non-random assignment of 136 third-year students, O1: pretest administered for experimental and control group respectively, O2: posttest administered for the control and experimental group, respectively, O3: retention test administered for the experimental and control group, $\mathrm{X}$ : treatment for innovative pedagogy; --no treatment

\section{Results}

What are the mean achievement scores of undergraduate students taught database management combining CBL and PBL strategy using google classroom and those taught with lecture method?

Table (2): Pre-test and Post-test mean scores of Undergraduate Students Taught Database Management Combining CBL and PBL Strategy using Google Classroom and those Taught with Lecture Method

\begin{tabular}{llcccl}
\hline & \multicolumn{1}{l}{ Pre-test } & \multicolumn{3}{l}{ Post-test } \\
Groups & N & $\overline{\mathrm{x}}$ & $\overline{\mathrm{x}}$ & SD & $\begin{array}{l}\text { Mean Gain } \\
\text { (Mg) }\end{array}$ \\
& SD & & & & \\
\hline Treatment & 58 & 25.05 & 70.71 & 45.66 \\
& 4.763 & & 7.061 & \\
Control & 78 & 25.01 & 56.22 & 31.707 \\
& 4.151 & & 7.717 & \\
& & & & \\
\hline
\end{tabular}

The result presented in Table 1 shows that year three students taught database management system combining CBL and PBL strategy using google classroom instructional delivery had a pretest achievement mean score of 25.05, post-test mean achievement score of 70.71 and mean achievement gain score of 45.66. On the other hand, students taught database with lecture method had a pre-test mean achievement score of 25.01, posttest mean achievement score of 56.22 making their mean achievement gain to be 31.707 . This result indicates that teaching database management system combining CBL and PBL strategy using google classroom as instructional delivery and lecture method appreciably increased academic achievement of the undergraduate year three students in database management. Students taught with combining CBL and PBL strategy using google classroom had higher achievement than the group taught with lecture method. Hence, combining CBL and PBL strategy using google classroom as instructional delivery is effective than using lecture teaching method on the student's academic achievement in a database management system. 
What is the interaction effect of treatment and gender on achievement scores of students taught database management?

Table (3): Mean Interaction Effect of Treatment and Gender on Achievement Scores of Students Taught Database Management

\begin{tabular}{|c|c|c|c|c|c|c|c|c|}
\hline \multirow[b]{2}{*}{ treatment } & \multirow[b]{2}{*}{ Gender } & \multirow[b]{2}{*}{$\mathbf{N}$} & \multicolumn{2}{|c|}{ Pre - Test } & \multicolumn{3}{|c|}{ Post - Test } & \multirow[b]{2}{*}{$\begin{array}{l}\text { Mean } \\
\text { Diff }\end{array}$} \\
\hline & & & $X_{1}$ & $\mathrm{SD}_{1}$ & $\boldsymbol{X}_{2}$ & $\mathrm{SD}_{2}$ & $\begin{array}{r}\text { Mean } \\
\text { Gain }\end{array}$ & \\
\hline \multirow{2}{*}{$\begin{array}{l}\text { CBL } \\
\text { and } \\
\text { PBL }\end{array}$} & $\mathbf{M}$ & 36 & 25.47 & 5.63 & 71.92 & 8.12 & 46.45 & \multirow{2}{*}{2.08} \\
\hline & $\mathbf{F}$ & 22 & 24.36 & 2.80 & 68.73 & 4.15 & 44.37 & \\
\hline \multirow{2}{*}{ LBM } & M & 51 & 24.47 & 4.59 & 56.63 & 8.46 & 31.16 & \multirow{2}{*}{0.13} \\
\hline & $\mathbf{F}$ & 27 & 24.15 & 3.05 & 55.44 & 6.14 & 31.29 & \\
\hline
\end{tabular}

The result presented in Table 3 shows the interaction effect of treatment and gender on achievement students taught database management combining CBL and PBL strategy using google classroom and lecture method. In the treatment, the result reveals that male students had a total mean achievement score of 24.57in the pre-test and 71.92 in the post-test making their overall mean achievement gain in database management to be 46.45 . On the other hand, female students had a total mean achievement score of 24.36 in the pre-test and 68.73 in the post-test making their overall mean achievement gain in database management to be 44.37 .

The male students taught database management using the Lecture Method had a pre-test mean score of 24.47and a post-test mean score of 56.63. On the other hand, female students had a total mean achievement score of 24.15 in the pre-test and 55.44 in the post-test making their overall mean achievement gain in database management to be 31.29. The difference between the pre-test and post-test means scores for male and female students taught database management combining CBL and PBL strategy using google classroom was 2.08. On the other hand, the difference between the pre-test and post-test means scores for male and female students taught database management using the lecture method was 0.13 . These results indicated that in all cases, the post-test mean achievement score was greater than the pre-test scores with the male students having a higher achievement in database management combining CBL and PBL strategy using google classroom as instructional strategy and Lecture Method.

There is no significant difference in the mean achievement scores of undergraduate students taught database management combining CBL and PBL strategy using google classroom and those taught with lecture method.
Table (4): Analysis of Covariance (ANCOVA) of the Significant difference in the Mean Academic Achievement Score of students taught database management combining CBL and PBL Strategy using Google Classroom and those Taught with Lecture Method.

\begin{tabular}{|l|c|c|c|c|c|}
\hline Source & $\begin{array}{c}\text { Sum of } \\
\text { Squares }\end{array}$ & DF & $\begin{array}{c}\text { Mean } \\
\text { Square }\end{array}$ & F & Sig. \\
\hline $\begin{array}{l}\text { Corrected } \\
\text { Model }\end{array}$ & $7022.251^{\mathrm{a}}$ & 2 & 3511.125 & $\mathbf{6 3 . 2 0 5}$ & $\mathbf{0 . 0 0 0}$ \\
\hline Intercept & 14791.996 & 1 & 14791.996 & $\mathbf{2 6 6 . 2 7 7}$ & $\mathbf{0 . 0 0 0}$ \\
\hline PRETEST & 39.004 & 1 & 39.004 & $\mathbf{0 . 7 0 2}$ & $\mathbf{0 . 4 0 4}$ \\
\hline GROUP & 6978.538 & 1 & 6978.538 & $\mathbf{1 2 5 . 6 2 4}$ & $\mathbf{0 . 0 0 0}$ \\
\hline Error & 7388.308 & 133 & 55.551 & & \\
\hline Total & 543912.000 & 136 & & & \\
\hline $\begin{array}{l}\text { Corrected } \\
\text { Total }\end{array}$ & 14410.559 & 135 & & & \\
\hline & a. R Squared $=.487$ (Adjusted R Squared =.480) & \\
\hline
\end{tabular}

\section{Note: Level of Sig. $=\mathbf{0 . 0 5}$}

The result in Table 4 shows that concerning academic achievement mean score students taught database management combining CBL and PBL strategy using google classroom and Lecture Method, an F-ratio of 125.624 was obtained with an associated probability value of 0.000 . Since the associated probability value of 0.000 was less than 0.05 set as a benchmark, the null hypothesis $(\mathrm{H} 01)$ which stated that there is no significant difference in the mean achievement scores of undergraduate students taught database management combining CBL and PBL strategy using google classroom and those taught with lecture method is rejected. An inference drawn therefore is that there was a significant difference in the mean academic achievement score of students taught database management combining CBL and PBL strategy using google classroom and those taught with lecture method, with those taught database management combining CBL and PBL strategy using google classroom approach having a higher mean gain.

There is no significant difference in the mean achievement scores of male and female undergraduate students taught database management combining CBL and PBL strategy using google classroom. 
Table (5): Analysis of Covariance (ANCOVA) of the Significant difference in the mean Academic Achievement Score of Male and Female Undergraduate Students Taught Database Management Combining CBL and PBL Strategy using Google Classroom

\begin{tabular}{|l|c|c|c|c|c|}
\hline Source & $\begin{array}{c}\text { Type III } \\
\text { Sum of } \\
\text { Squares }\end{array}$ & Df & $\begin{array}{c}\text { Mean } \\
\text { Square }\end{array}$ & F & Sig. \\
\hline $\begin{array}{l}\text { Corrected } \\
\text { Model }\end{array}$ & $7169.958^{\mathrm{a}}$ & 4 & 1792.489 & 32.430 & .000 \\
\hline Intercept & 14889.367 & 1 & 14889.367 & 269.385 & .000 \\
\hline Pretest & 23.101 & 1 & 23.101 & .418 & .519 \\
\hline Group & 6275.707 & 1 & 6275.707 & 113.543 & .000 \\
\hline Gender & 129.800 & 1 & 129.800 & 2.348 & .128 \\
\hline $\begin{array}{l}\text { Group * } \\
\text { Gender }\end{array}$ & 31.620 & 1 & 31.620 & 0.572 & .451 \\
\hline Error & 7240.601 & 131 & 55.272 & & \\
\hline Total & 543912.000 & 136 & & & \\
\hline $\begin{array}{l}\text { Corrected } \\
\text { Total }\end{array}$ & 14410.559 & 135 & & & \\
\hline \multicolumn{7}{|l|}{ a. R Squared $=.498$ (Adjusted R Squared = .482) } \\
\hline
\end{tabular}

The result in Table 4 shows that concerning academic achievement mean score of male and female students taught database management combining CBL and PBL strategy using google classroom, an F-ratio of 0.572 was obtained with an associated probability value of 0.451 . Since the associated probability value of 0.451 is greater than 0.05 set as a benchmark, the null hypothesis ( $\mathrm{H} 02)$ stated that there is no significant difference in the mean achievement scores of male and female undergraduate students taught database management combining CBL and PBL strategy using google classroom is not rejected. An inference drawn therefore is that, there was no significant difference in the mean achievement scores of male and female undergraduate students taught database management combining CBL and PBL strategy using google classroom.

\section{Discussing of Findings}

The findings of this study in respect to the effect of combining CBL and PBL strategy using google classroom on students' academic achievement in database management was higher than the main effect of the lecture method. Hence, the difference between the main effect of combining CBL and PBL strategy using google classroom and lecture method was statistically significant. This finding implies that combining CBL and PBL strategy using google classroom is more effective than the lecture method in enhancing students' achievement in database management. These findings support Peterson, Dumont, Lafuente and Law, (2018) who found that the adoption innovative pedagogies in teaching practice course improve learner's interactivity, thus helping students to understand the tenets of the various topics discussed during the lecture and therefore developed a deep understanding of the concepts taught. In this regard, the findings of this study could be attributed to students' active participation in the learning process through the use of combining CBL and PBL strategy using google classroom to facilitate teaching and learning. Hence, engagement of students with innovative technologies is found to have a positive effect in improving desired outcomes for the students.

Furthermore, the researchers found that both male and female students in the treatment group had mean scores higher than those of the control group. Also, the ANCOVA output confirmed that there was a significant difference between the achievement of male and female students in database management. This finding affirms that a disparity exists in male and female students' performance in database management courses. In this regard, the findings of this study could be attributed to students' active participation in the learning process through the use of combining CBL and PBL strategy using google classroom. It can therefore be inferred that in combining CBL and PBL strategy using google classroom in teaching and learning of database management, male students tend to experience significant achievement gains compared to female students. There was no significant interaction effect of group and gender. This result is in contrast with the findings of Giri, and Paily, (2020) who found a statistically significant difference in favour of female achievement in Biology whereas there was no significant interaction observed between gender and treatment. These findings imply that undergraduate students seem to prefer learning database management with combining CBL and PBL strategy using google classroom. Computer educators should adopt the use of innovative pedagogies in teaching and learning database management to attain higher learning outcomes.

The data presented in Table 3 provided an answer to research question 2 . The findings revealed that male students had a mean score higher than the female students in the database management achievement test. Also, an Analysis of Covariance was employed to test the second hypothesis. Table 3 showed the F-calculated value 0.572 , the significance value 0.451 and confidence level of 0.05 , thus there is no significant difference between the main effect of gender (male and female) on students' achievement in database management which confirmed that difference between the achievement of male and female students in database management was not statistically significant. The obvious implication of this finding is that there was no effect attributed to gender on the achievement of students in database management. The findings upheld that disparity does not exist between male and female students' performance in a database course. The finding is in line with Ho, La, Nguyen, Pham, Vuong, Vuong, and Vuong, (2020), who found that male and female students are consistently performing better in vocational and technical achievement tests hence suggesting that males and females possess greater vocational and technical skills. The identified gender effect on achievement in database management was not relevant.

\section{Conclusion}

Based on the findings of the study, it was concluded that combing CBL and PBL instructional strategy using google classroom is more effective than the lecture method in 
improving student's achievement in database management. This high achievement gains recorded in combing CBL and PBL instructional strategy using google classroom is attributed to the level of student's pace learning, flexibility, and virtual learning increased mentoring of students which makes the students active participants in a database.

\section{Recommendations}

Based on the findings and implications of this study, the following recommendations were made:

1) The Nigerians Universities should adopt combing CBL and PBL instructional strategies using google classroom in teaching and learning of databases. Also, combing CBL and PBL instructional strategy using google classroom should be used as a medium of instruction at all levels of the Nigerian educational system as part of their teaching methods, especially in COVID-19.

2) Instructional materials to facilitate quality teaching and learning with the use of these modern teaching techniques should be provided by the government and school administrators.

\section{References}

[1] Aguboshim, F. C., Onwuka, I. N., Obiokafor, I. N., \& Oboti, N. P. (2021). Factors challenging research and innovation in tertiary education in Nigeria. World Journal of Advanced Research and Reviews, 10(1), 224-229.

[2] Albanese, M. A., \& Mitchell, S. (1993). Problembased learning: A review of literature on its outcomes and implementation issues. Academic Medicine-Philadelphia-, 68, 52-52.

[3] Al-Maroof, R. S., \& Salloum, S. A. (2021). An Integrated model of continuous intention to use of google classroom. In Recent Advances in Intelligent Systems and Smart Applications 1. 311-335

[4] Ataei, P. S. (2021). Theory and Implementation of a Variational Database Management System

[5] Recent Advances in Intelligent Systems and Smart Applications 1-45-56

[6] Azhar, K. A., \& Iqbal, N. (2018). Effectiveness of Google classroom: Teachers' perceptions. Prizren Social Science Journal, 2(2), 52-66.

[7] Balan, L., Yuen, T., \& Mehrtash, M. (2019). Problem-based learning strategy for CAD software using free-choice and open-ended group projects. Procedia Manufacturing, 32, 339-347.

[8] Carlos, R. (2021). Developing Best Practices to Ensure that Students Gain Context-Based Skills and Knowledge in Work-Based Learning Opportunities (Doctoral dissertation, Northeastern University).

[9] Chan, K. W., \& Elliott, R. G. (2004). Relational analysis of personal epistemology and conceptions about teaching and learning. Teaching and teacher education, 20(8), 817-831.

[10] Emelife, J. C. ( ). Critical pedagogy in Nigerian education: prospect and limitations s. education and development, 135, 3-24.
[11] Fakhimuddin, M., Khasanah, U., \& Trimiyati, R. (2021). Database Management System in Accounting: Assessing the Role of Internet Service Communication of Accounting System Information. Research Horizon, 1(3), 100-105.

[12] Francom, G. M., Schwan, A., \& Nuatomue, J. N. (2021). Comparing Google classroom and D2L Brightspace using the technology acceptance model. Tech Trends, 65(1), 111-119.

[13] Getz, C., Mathew, J., \& Shin, G. (2021). Chemistry in Real Life: The Effect of Context-Based Learning on Student Participation in Remote Workshops.

[14] Giri, V., \& Paily, M. U. (2020). Effect of collaborative scientific argumentation strategy on achievement in biology among 12th grade students. Journal of Critical Review, 7(3), 344-353.

[15] Gleason, B., \& Heath, M. K. (2021). Injustice embedded in Google Classroom and Google Meet: A techno-ethical audit of remote educational technologies. Italian Journal of Educational Technology, 29(2), 26-41.

[16] Gupta, A., \& Pathania, P. (2021). To study the impact of Google Classroom as a platform of learning and collaboration at the teacher education level. Education and Information Technologies, 26(1), 843-857.

[17] Ho, M. T., La, V. P., Nguyen, M. H., Pham, T. H., Vuong, T. T., Vuong, H. M., ... \& Vuong, Q. H. (2020). An analytical view on STEM education and outcomes: Examples of the social gap and gender disparity in Vietnam. Children and Youth Services Review, 119, 105650.

[18] Huang, T. H., Liu, F., Chen, L. C., \& Tsai, C. C. (2021). The acceptance and impact of Google Classroom integrating into a clinical pathology course for nursing students: A technology acceptance model approach. PloS one, 16(3), e0247819.

[19] Ismail, I., Mustakim, M., \& Samad, I. S. (2021). Integrating Google Classroom in Teaching: Changing the Learning Culture in Higher Education during a Pandemic. MAJESTY Journal, 3(1), 22-36.

[20] Ivongbe, M. I., Abdulsalami, L. T., \& Omorogbe, H. O. (2021). Application of Database Management System in the Library of Federal University, Lafia.

[21] Jeon-Ellis, G., Debski, R., \& Wigglesworth, G. (2005). Oral interaction around computers in the project-oriented CALL classroom. Language Learning \& Technology, 9(3), 121-145.

[22] Kalyani, D., \& Rajasekaran, K. (2018). Innovative teaching and learning. Journal of Applied and Advanced Research, 3(1), 23-25.

[23] Khairani, S., Suyanti, R. D., \& Saragi, D. (2020). The Influence of Problem Based Learning (PBL) Model Collaborative and Learning Motivation Based on Students' Critical Thinking Ability Science Subjects in Class V State Elementary School 105390 Island Image. Budapest International Research and Critics in Linguistics and Education (BirLE) Journal, 3(3), 1581-1590. 
[24] Khamroevich, U. O. (2021). Innovative technologies and methods training in education. Academica: An International Multidisciplinary Research Journal, 11(1), 1304-1308.

[25] Khan, M. A. A., \& Sobani, Z. A. (2012). Influence of gender and ethnicity on problem-based learning. Journal of Pakistan Medical Students, 2(3), 122-125.

[26] Korucu-Kış, S. (2021). Preparing student teachers for real classrooms through virtual vicarious experiences of critical incidents during remote practicum: A meaningful-experiential learning perspective. Education and Information Technologies, 3, 1-23.

[27] Li, H., Zhang, H., \& Zhao, Y. (2021). Design of computer-aided teaching network management system for college physical education. ComputerAided Design and Applications, 18(S4), 152-162.

[28] Luik, P., \& Lepp, M. (2021). Are Highly Motivated Learners More Likely to Complete a Computer Programming MOOC?. International Review of Research in Open and Distributed Learning, 22(1), 41-58.

[29] Majherová, J., \& Králík, V. (2017). Innovative Methods in Teaching Programming for Future Informatics Teachers. European Journal of Contemporary Education, 6(3), 390-400.

[30] Naik, S., \& Gajjar, K. (2021). Applying and Evaluating Engagement and Application-Based Learning and Education (ENABLE): A StudentCentered Learning Pedagogy for the Course Database Management System. Journal of Education, 00220574211032319.

[31] Nicolaides, A. (2012). Innovative teaching and learning methodologies for higher education institutions. Educational research, 3(8), 620-626.

[32] Northwood, M. D., Northwood, D. O., \& Northwood, M. G. (2003). Problem-Based Learning (PBL): from the health sciences to engineering to value-added in the workplace. Global J. of Engng. Educ, 7(2), 157-163.

[33] Numonjonov, S. D. (2020). Innovative methods of professional training. ISJ Theoretical \& Applied Science, 1(81), 747-750.

[34] Obaroakpor, T., Dikenwosi, R. N., \& Obaroakpor, K. I. (2021). Factors Militating Against Technical Education Instructions in Nigeria Technical Schools. Mosogar Journal of Vocational and Technical Education, 1(1).

[35] Oguguo, B. C., Nannim, F. A., Agah, J. J., Ugwuanyi, C. S., Ene, C. U., \& Nzeadibe, A. C. (2021). Effect of learning management system on Student's performance in educational measurement and evaluation. Education and Information Technologies, 26(2), 1471-1483.

[36] Oktaria, A. A., \& Rahmayadevi, L. (2021). Students' perceptions of using google classroom during the covid-19 pandemic. International Journal of Educational Management and Innovation, 2(2), 153163.
[37] Olimov, S. S. (2021). The innovation process is a priority in the development of pedagogical sciences.

[38] Onyepunuka Michael, I., Fumnanya, E., \& Eze, E. C. P. (2021). Effects of Access Database Management System Hands-on Experience on Students' Academic Achievement and Self-Efficacy in Database Management. International Journal of Psychosocial Rehabilitation, 25(03)

[39] Ouatik, F., \& Ouatik, F. (2021, May). Learning Management System Comparison: New Approach Using Multi-Criteria Decision Making. In International Conference on Business Intelligence (pp. 239-248). Springer, Cham.

[40] Ovchinin, A. A., Kuligina, N. O., \& Tarlakovskaya, E. A. (2021). Analysis and solution of the problem of server protection with a database management system using the example of the" oracle" dbms. In Сборник избранных статей по материалам научных конференций ГНИИ" Нацразвитие" (4042).

[41] Pachacama, P., Cuascota, L., \& Guerrero, G. (2021, March). Authoring Tool for the Creation of Learning Objects in Occupational Education to Support People with Cognitive Disabilities. In World Conference on Information Systems and Technologies (pp. 194204). Springer, Cham.

[42] Peterson, A., Dumont, H., Lafuente, M., \& Law, N. (2018). Understanding innovative pedagogies: Key themes to analyse new approaches to teaching and learning.

[43] Savery, J. R. (2015). Overview of problem-based learning: Definitions and distinctions. Essential readings in problem-based learning: Exploring and extending the legacy of Howard S. Barrows, 9(2), 515.

[44] Sgroi, C. A., \& Ryniker, M. (2002). Preparing for the real world: A prelude to a fieldwork experience. Journal of Criminal Justice Education, 13(1), 187200.

[45] Süer, S., \& Oral, B. (2021). Innovative Pedagogical Practices Scale for Teachers: A Study of Validity and Reliability. Mersin University Journal of the Faculty of Education, 17(1).

[46] Thomas, C. E. Blended teaching and learning in Tertiary Education with Google Classroom.

[47] Yelamali, V., \& Beelagi, S. (2021). The Results of Classification of Lab Assignment in Object Oriented Programming and Database Management System Lab: A Case Study. Journal of Engineering Education Transformations, 34, 277-280.

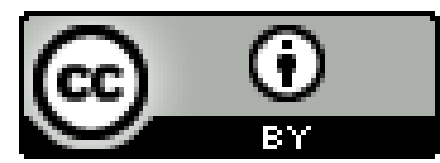

